\title{
VARIATION IN THE RELATION OF RAINFALL TO RUNOFF FROM RESIDENTIAL LAWNS IN MADISON, WISCONSIN, JULY AND AUGUST 1995
}

By Andrew D. Legg, Roger T. Bannerman, and John Panuska

U.S. GEOLOGICAL SURVEY

Water-Resources Investigations Report 96-4194

Prepared in cooperation with the WISCONSIN DEPARTMENT OF NATURAL RESOURCES

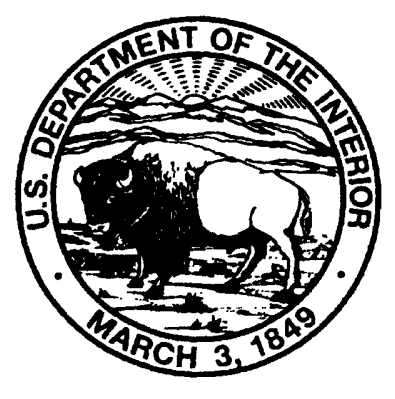

Madison, Wisconsin 


\title{
U.S. DEPARTMENT OF THE INTERIOR BRUCE BABBITT, Secretary
}

\author{
U.S. GEOLOGICAL SURVEY \\ Gordon P. Eaton, Director
}

For additional information write to:

Copies of this report can be purchased from:

District Chief

U.S. Geological Survey

6417 Normandy Lane

Madison, WI 53719
U.S. Geological Survey

Branch of Information Services

Box 25286

Denver, CO 80225-0286 


\section{CONTENTS}

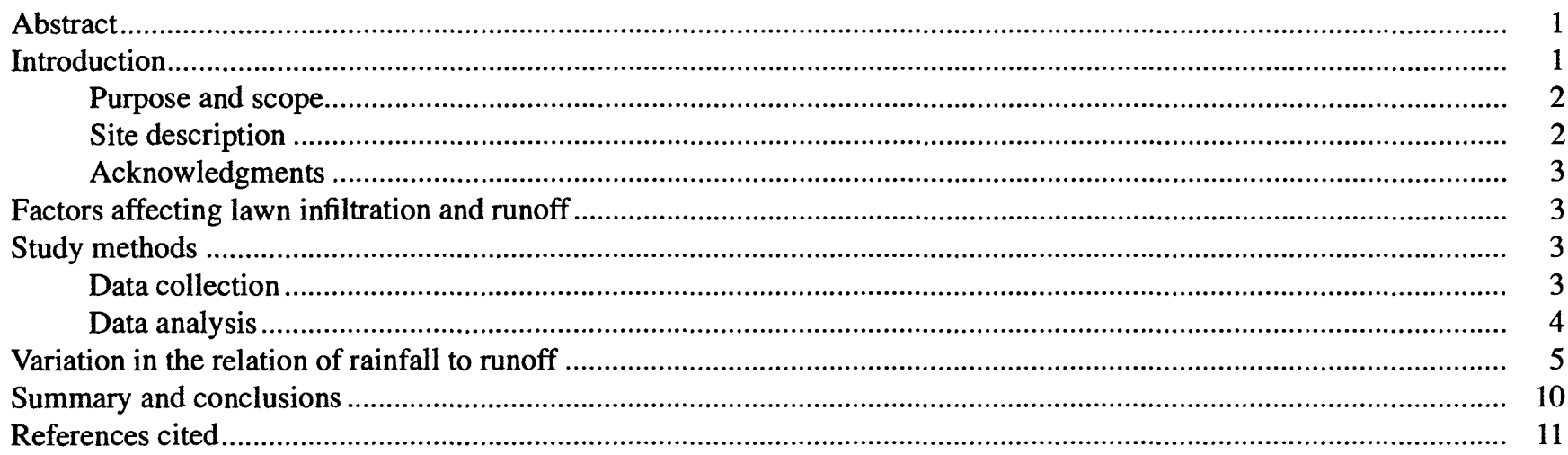

\section{FIGURES}

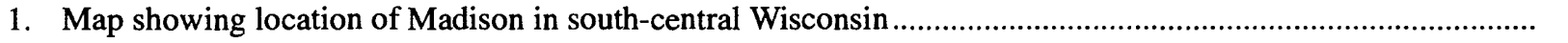

2-5. Graphs showing:

2. Cumulative rainfall versus runoff coefficients for three locations on the same residential lawn before and after normalization for equal antecedent soil moisture

3. Cumulative rainfall versus runoff coefficients for three different lawns before and after normalization for equal antecedent soil moisture

4. Cumulative rainfall versus runoff coefficients for five different lawn age groups before and after normalization for equal antecedent soil moisture.

5. Runoff coefficients for a single lawn for three different rainfall intensities

\section{TABLES}

1. Soil characteristics and average Green-Ampt parameters for three locations on a single lawn .............................. 6

2. Soil characteristics and average Green-Ampt parameters for three different lawns .............................................. 8

3. Soil characteristics and average Green-Ampt parameters for five different age groups ....................................... 8

\section{CONVERSION FACTORS}

\begin{tabular}{rll}
\hline Multiply & By & To Obtain \\
\hline centimeter $(\mathrm{cm})$ & & inch \\
centimeter per hour $(\mathrm{cm} / \mathrm{hr})$ & 0.3937 & inch per hour \\
gram $(\mathrm{g})$ & 0.3937 & pound \\
meter $(\mathrm{m})$ & $2.205 \times 10^{-3}$ & foot
\end{tabular}

Degree Celsius $\left({ }^{\circ} \mathrm{C}\right)$ may be converted to degree Fahrenheit $\left({ }^{\circ} \mathrm{F}\right)$ by using the following equation:

$$
{ }^{\circ} \mathrm{F}=9 / 5\left({ }^{\circ} \mathrm{C}\right)+32 \text {. }
$$




\title{
Variation in the Relation of Rainfall to Runoff from Residential Lawns in Madison, Wisconsin, July and August 1995
}

\author{
By Andrew D. Legg ${ }^{1}$, Roger T. Bannerman ${ }^{2}$, and John Panuska ${ }^{2}$
}

\section{Abstract}

The quality of runoff from residential lawns is a concern for municipal stormwater management programs. Land-use based computer models are increasingly being used to assess the impact of lawn runoff on urban watersheds. To accurately model the runoff for residential lawns, the variation in the relation of rainfall to runoff from lawns must be understood. The study described in this report measures the runoff parameters from 20 residential lawns in Madison, Wisconsin, using a rainfall simulator. It was determined that the saturated hydraulic conductivity does not vary significantly within a single residential lawn, but does vary significantly from one lawn to another. This variation is recognized in the entire rainfall-runoff relation from one lawn to another. The age of a lawn, or the years since development and turf establishment, is used as a surrogate of several lawn and soil characteristics to describe the variability in lawn runoff volumes. Runoff volumes from newly developed lawns are significantly greater than runoff from older lawns. This is an important consideration when modeling runoff for new developments. For older lawns, the date since lawn establishment does not explain the variation in the rainfall-runoff relation. In order for simple land-use based computer models to adequately account for the volume of runoff from pervious landscapes, field data from individual lawns would be necessary. A more realistic, alternative method may be to consider a basin-scale analysis of runoff from pervious landscapes.

\section{INTRODUCTION}

The residential lawn is a typical landscape in many urban watersheds throughout the United States.
For several urban watersheds in Wisconsin, turf areas account for as much as 65 percent of the entire land cover (Bannerman and others, 1996). The quality of stormwater that washes off urban watersheds, including residential lawns, is of concern for municipal stormwater management programs. The 1987 Amendments to the Clean Water Act have legitimized these concerns. The Amendments call for development of site-specific municipal stormwater management programs. States are now in the process of developing management programs for municipalities with populations of 100,000 or more.

Simple land-use based computer models are being used increasingly in the development of stormwater-quality management programs. The Source Loading and Management Model (SLAMM) is being used by the Wisconsin Department of Natural Resources (WDNR) for estimating pollutant loads from particular urban land uses. Specifically, SLAMM is being used to develop watershed management plans and to evaluate best-management practices for urban watersheds in Wisconsin (Pitt, 1986). The work on which this report is based was performed by the U.S. Geological Survey (USGS) in cooperation with the WDNR in order to improve the modeling capability of SLAMM. SLAMM uses concepts of small-storm hydrology and a formulation similar to the rational formula to calculate the volume of runoff from different urban land uses. The runoff parameters used in the rational formula for residential lawns were developed initially for agricultural purposes and are based on characteristics of bare, native soils. Typically, during lawn establishment native soils are excavated, the construction area may be filled with non-native soils, soils are subjected to compaction by construction equipment, and finally grass is established using either seed or sod. These lawn establishment methods alter the

\footnotetext{
${ }^{1}$ U.S. Geological Survey, Madison, Wis.

${ }^{2}$ Wisconsin Department of Natural Resources, Madison, Wis.
} 
runoff characteristics of soils; therefore, the use of existing runoff parameters may be inaccurate. As also recognized by Watschke and others (1989), there is a need to develop runoff parameters for lawns to more accurately model urban landscapes.

The study described in this report determines whether rainfall infiltration into residential lawns can be accurately modeled without intensive data collection. To meet the objectives of simple hydrologic computer models, it is most practical for runoff parameters to be determined on a regional basis and not be specific to individual lawns. Therefore, fundamental to understanding the relation between rainfall and runoff for residential lawns is understanding the variability of runoff volumes from lawns. Hamilton (1990) and Kelling and Peterson (1975) measured infiltration rates for lawns and found considerable variation between measurements.

\section{Purpose and Scope}

This report describes the results of a study of the rainfall-runoff relation from 20 residential lawns in Madison, Wisconsin, using a portable rainfall simulator. For this study, three hypotheses were tested to determine the variation in the relation between rainfall and runoff from residential lawns. Hypothesis 1: there are no substantial differences in the rainfall-runoff relations within a single lawn. Hypothesis 2: there are substantial differences in the rainfall-runoff relations from different lawns. Hypothesis 3: there is a relation between the age of a lawn, or the years since development and turf establishment, and the volume of runoff from a lawn. The age of a lawn was used as a surrogate of several lawn and soil characteristics to describe the variability in lawn runoff volumes. After soil grading and turf establishment, physical, chemical, and biological processes described in the section "Factors Affecting Lawn Infiltration and Runoff" will develop pore space and macropores in the soil matrix. It is believed that as the lawn ages, soil develops and the runoff from a lawn will decrease. This is supported by Partsch and others (1993), who recognized some trend towards faster infiltration with age after measuring infiltration rates on 6- and 12-year old lawns. Although it may be an oversimplification of the infiltration process, the age of a lawn would be a practical consideration for simple land-use based computer models that are limited in their accuracy by their broader management objectives.
Finally, the importance of antecedent soil moisture, rainfall intensity, and soil texture as they affect the rainfall-runoff relation on residential lawns is discussed.

\section{Site Description}

The data for this study were collected from 20 residential lawns in Madison, Wisconsin (fig. 1). Madison is located in south-central Wisconsin and has a northern temperate climate. The seasons in Madison were framed by a summer high temperature of $38^{\circ} \mathrm{C}$ and a winter low temperature of $-22^{\circ} \mathrm{C}$ for $1994-95$. The data were collected during July and August 1995. Total rainfall amounts recorded for south-central Wisconsin during July and August were 10.5 and $14.2 \mathrm{~cm}$, respectively. These amounts are 109 percent and 140 percent of the normal for the period of record 1961-95 (Pamela Naber-Knox, Wisconsin State Climatologist, oral commun., 1995). The soils for the study sites were mapped by the Soil Conservation Service (Glocker and Patzer, 1978) as silt loam of the Dodge, McHenry, and St. Charles Series. These series generally consist of deep, well-drained soils on glaciated uplands with hydraulic conductivity between 1.6 and $5.1 \mathrm{~cm} / \mathrm{hr}$.

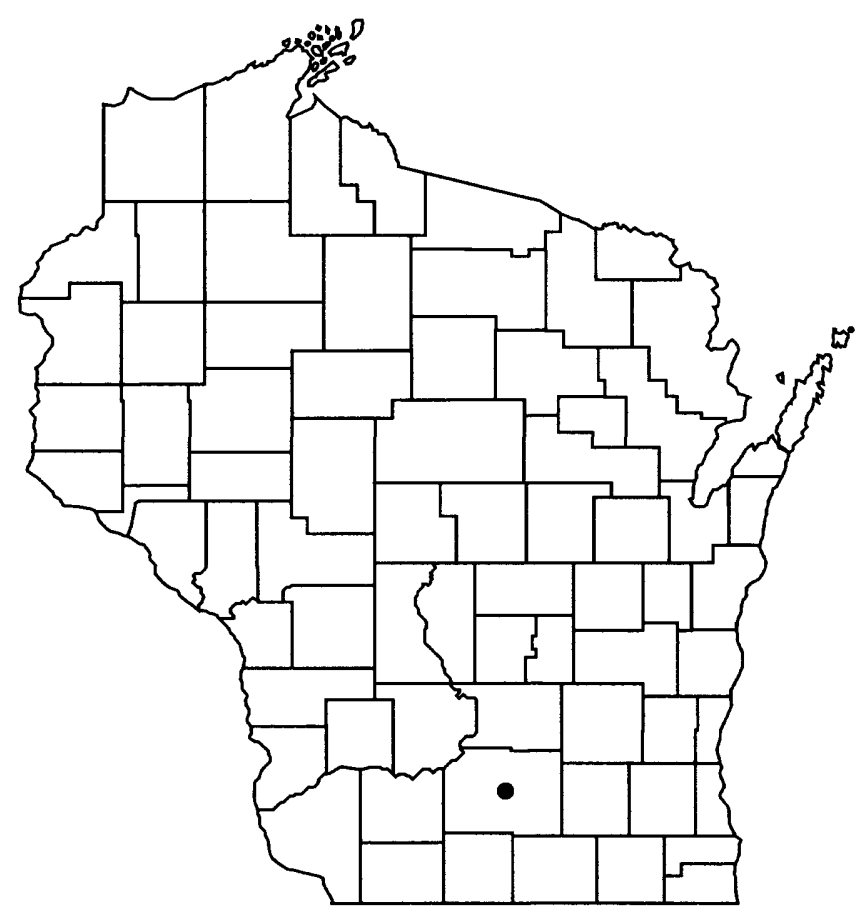

Figure 1. Location of Madison in south-central Wisconsin. 


\section{Acknowledgments}

Thanks are extended to Kevin Silvera and the University of Wisconsin Soils Department for use and operation of their rainfall simulator. The author also thanks Howard Gundlock of the Natural Resources Conservation Service for his help with the soil texture analysis, and John Panuska and Roger Bannerman of the Wisconsin Department of Natural Resources for providing insight for this study.

\section{FACTORS AFFECTING LAWN INFILTRATION AND RUNOFF}

The infiltration rate of turf grass has received increasing attention because of the potential for surface water-quality-degradation from nutrient and pesticide runoff from residential lawns. Effects of turf grass on the infiltration process have been investigated in a few studies, and many more studies have investigated the effects of soil characteristics on the infiltration process.

Hino and Shutto (1987) found that grass-covered soil had a higher soil moisture content and moisture conductivity than did bare soil. They concluded that grass roots transformed the structural characteristics of the soil to increase saturated hydraulic conductivity from $0.6 \mathrm{~cm} / \mathrm{hr}$ for bare soil to $10 \mathrm{~cm} / \mathrm{hr}$ for grass-covered soils. Gross and others (1991) studied lawns established at different seeding rates and suggested that a thick, dense and thatchy lawn may absorb and infiltrate all rainfall from light to moderate intensities.

Many researchers have demonstrated that antecedent soil moisture is an important factor in producing runoff. Tisdall (1951) recognized that as soil antecedent moisture contents increased, infiltration rates decreased. Istok and Boersma (1986) concluded that antecedent moisture is more important than the magnitude or intensity of rainfall in controlling the occurrence and amount of runoff. Watschke and others (1989) observed a seasonal change in runoff volumes in response to antecedent moisture conditions affected by seasonal changes in water uptake for plant growth.

The volume of pore space in a soil matrix affects the hydraulic conductivity of a soil. Pore space, or the void space in the soil matrix, is increased as the aggregation of soil mineral particles increases, and that, in turn, increases the hydraulic conductivity of the soil. The destruction of the natural soil matrix as a consequence of excavation and compaction can, therefore, decrease the hydraulic conductivity. The effect on infil- tration of soil compaction from lawn construction and every-day foot traffic has been studied. Kelling and Peterson (1975) observed infiltration rates under simulated rainfall to be highest on lawns with undisturbed soil structure. They noticed that infiltration rates were affected locally on a lawn by compaction from foot traffic and recreational uses. Partsch and others (1993) studied bulk densities of established lawns and observed that compacting the soil after stripping the topsoil creates a limiting layer that reduces the rate at which water can infiltrate. Kussow (1994) studied naturally occurring rainfall runoff from compacted and noncompacted turf plots. Initial results of this study show that soil disturbances, such as those that occur in urban settings, increase runoff from turf, but not as much as expected.

The volume of pore space in a soil matrix is also affected by the presence of macropores. Macropores close to the surface of the soil create preferential pathways for infiltrating rainwater. In their review of the importance of macropores on water flow in soils, Beven and Germann (1982) suggest macropores may dominate vertical flow of water through soils. They grouped the formation of macropores by the following: (1) those formed by soil fauna, including the activities of burrowing animals, earthworms, and ants; (2) those formed by plant roots; (3) those caused by cracks; (4) fissures in the soil matrix from shrinking and swelling soils or freeze/thaw cycles; and (5) natural soil pipes, formed by the erosive action of subsurface flows. All of these types of macropores may be destroyed when a lawn is established but will redevelop in a lawn over time. Under favorable circumstances, macropore systems can be developed in as little as 1 to 2 years and last for considerable time in a stable soil structure (Beven and Germann, 1982). Hino and Shutto (1987) found that the growth of grass altered the structure of soils within 2 months of establishment.

\section{STUDY METHODS}

\section{Data Collection}

A Modified Purdue Model Sprinkling Infiltrometer as described by Peterson and Bubenzer (1986) was used to simulate rainfall in this study. The rainfall simulator was operated at an intensity of $7.1 \mathrm{~cm} / \mathrm{hr}$, which is approximately equivalent to a 50-year storm in southern Wisconsin (Huff and Angel, 1992). It was 
necessary to operate the rainfall simulator at this high intensity to produce runoff on all of the lawns without varying the intensity for a particular measurement. Rainfall was simulated on 1-by-1 m sections of residential lawn confined by a steel frame. Runoff from the simulated rainfall was collected by vacuuming the surface ponded water into a volumetrically calibrated container (Peterson and Bubenzer, 1986). For each measurement site, the simulator "rained" for $60 \mathrm{~min}$ utes, and runoff volumes were measured every 5 minutes. If runoff did not occur within the first 30 minutes, the simulated rainfall was extended to 90 minutes. In an attempt to reach saturated soil conditions, at least four consistent runoff volumes were measured before the rainfall simulator was turned off. The incremental runoff data collected was then used to plot cumulative runoff curves for this study.

Along with the runoff measurements, surface bulk density, antecedent moisture content, and organic matter content measurements were made from the surface soils. Soil moisture samples were measured gravimetrically (Gardner, 1986). A 30-cm soil core was logged for each site. The soil texture was described using hand texturing, and the soil structure was visually inspected. The soils were all classified as silt loam with varying degrees of structural development.

Turf conditions and maintenance practices were noted for residential lawns in the study. All of the runoff measurements were made on turf with a 10 -percent slope. The turf at each measurement site was mowed to the same height prior to the start of simulated rainfall.

The data for this study were collected according to a design appropriate for statistical analysis. The study was designed in three parts to test the hypotheses. Each part of the study includes measurement sets consisting of four replicates. Different measurement sets are the experimental units being compared in the study. A replicate is one rainfall-simulator test, with runoff data collected as described above.

Part 1: to examine the variation within a single lawn

- 1 lawn

- 3 sets-randomly located within lawn

- replicates located side-by-side

Part 2: to examine the runoff variation among different lawns

- 3 lawns

- 3 sets-one in each lawn

- replicates randomly located within a lawn
Part 3: to examine the runoff variation for lawns of different age groups

- 20 lawns

- 5 sets of 4 lawns each-sets represent different age groups (the five age-group sets used in this study were $1-3,7-9,13-16,41-46$, and $65-70$ years old)

- replicates are 1 measurement on each of the 4 lawns within an age group

\section{Data Analysis}

To quantify the variability in the relation of rainfall to runoff, the measurement sets described above were compared statistically. The average of four replications for each measurement set were compared by analysis of the variance (ANOVA) (Helsel and Hirsch, 1995) to determine significant differences. Tukey's method for multiple comparison was used to compare and rank the average values of the different age-group sets (Helsel and Hirsch, 1995). For these statistical tests, an observed significance level ( $\mathrm{p}$-value) less than 0.05 was considered significantly different. The rainfall-runoff relations for measurement sets were compared graphically by plotting cumulative rainfall versus runoff coefficients. Each plot represents the average rainfall-runoff relation from four replications. The runoff coefficient is the ratio of cumulative runoff to cumulative rainfall. By plotting the rainfall-runoff relation as the cumulative rainfall versus runoff coefficient, the effects of the variability on the entire runoff process are more apparent, although not quantified.

To statistically compare measurement sets, soil matrix parameters describing the entire cumulative runoff curve were determined from the Green-Ampt infiltration model, as modified by Mein and Larson (1973). Runoff data collected in the field was used to calibrate the Green-Ampt model.

The formulation of the Green-Ampt model used in this study was:

$$
t=\frac{1}{K}\left[F-F_{r}+\Psi(n) \ln \left(\frac{\Psi(n)+F_{r}}{\Psi(n)+F}\right)\right]+t r,
$$

where

$t \quad$ is time since rainfall began (hr);

$K$ is saturated hydraulic conductivity $(\mathrm{cm} / \mathrm{hr})$;

$F$ is volume of rainfall infiltrated $(\mathrm{cm})$; 
$F_{r}$ is volume of rainfall infiltrated at the time runoff began $(\mathrm{cm})$;

$\psi$ is wetting front soil suction head (cm);

$n$ is available pore space (percent); and

$t_{r}$ is elapsed time from the beginning of rainfall

to the beginning of runoff $(\mathrm{hr})$.

For this formulation of the Green-Ampt model, $t$ is the dependent variable and $F$ is the independent variable. Values for $t$ were calculated using parameters determined at each measurement site as follows. $K$ was calculated from the field data by a linear regression analysis on the cumulative runoff curve when the soil had reached an apparent steady state or saturation. The elapsed time from when rainfall begins to the time water begins to runoff the soil surface, $t_{r}$ was taken directly from the cumulative runoff curve determined in the field. The volume of rainfall infiltrated at the time runoff began, $F_{r}$ is equal to the rainfall intensity multiplied by $t_{r}$ Available pore space, $n$, was calculated as $\phi-\theta_{i}$, where $\phi$ is 95 percent of the soil porosity and $\theta_{\mathrm{i}}$ is the initial soil moisture. The wetting front suction parameter $(\psi)$ was not easily determined from the measured data. To complete the model $\psi$ was determined using a curve fitting method similar to that described by Partsch and others (1993). To obtain $\psi$, the Green-Ampt model was fit to the cumulative runoff field data. A value for $\psi$ was chosen which resulted in the least square difference between $t$ calculated and $t$ values from field measurements. Unlike the physically derived parameters $t_{r}$ and $K, \psi$ is empirically calculated. To measure how well the model fit the field data, $t$ calculated was correlated to field measured $t$ values. An $R^{2}$ value of 1.0 was a perfect match between model and field data.

Repeating the above calculations, the parameters $t_{r} \psi$, and $K$ were determined for each replication of each measurement set. The cumulative runoff curve then was completely defined by the Green-Ampt parameters: $t_{r}$ is the time until runoff occurs, $\psi$ describes how quickly the soil reaches saturation after runoff has begun, and $K$ describes the runoff curve at saturation. The averages of the Green-Ampt parameters for each measurement set were statistically compared, and the average rainfall-runoff relation was drawn for each measurement set.

An attempt was made to use $K$ instead of $\psi$ as the curve fitting parameter in the Green-Ampt model. $\psi$ values were instead calculated based on soil properties and regression equations formulated by Rawls and Brakenseik (1989). This method was not used because it resulted in negative Green-Ampt parameters. Other researchers have also encountered negative parameters when using a least-squared estimation for Green-Ampt parameters (Devaurs and Gifford, 1986).

As noted in the literature, runoff volumes are dependent on the antecedent soil moisture. The observed antecedent soil moisture contents varied substantially during this study, ranging from 8.2 to 43.5 percent. To account for the varying soil moisture conditions, the runoff data were normalized to an equal soil moisture, $\theta_{i}=21$ percent. This value is the average of the field capacity (28.4 percent) and the permanent wilt point (13.5 percent) for a silt loam soil (Rawls and others, 1983). The $t_{r}$ parameter was normalized for the equal soil moisture conditions by recalculating $n$ at the average soil moisture. $K$ and $\psi$ are a function of the soil matrix and not soil moisture; therefore, these parameters did not need adjustment. After being normalized for an equal soil moisture, average $t_{r}$ values for each measurement set were again statistically compared, and normalized rainfall-runoff relations drawn.

\section{VARIATION IN THE RELATION OF RAINFALL TO RUNOFF}

Rainfall-runoff measurements and turf characteristics were collected from 20 residential lawns to compare the variation in residential lawn runoff. Three hypothesis concerning the variation of lawn runoff and the causes of that variation were tested.

The first hypothesis stated there are no substantial differences in the rainfall-runoff relations within a single lawn. For the first part of the study, measurements were made at three different locations within the same lawn with four replications per location. Table 1 lists the soil characteristics, Green-Ampt parameters, and $\mathrm{p}$-values for the three different locations.

The model and field data compared very well as determined by the $\mathrm{R}^{2}$ correlation coefficients.

ANOVA's calculated for average $K$ values were not significantly different, which suggests that the soil properties did not vary for the lawn. The mean values of the time of ponding, $t_{r}$ for three measurement sets were significantly different within the same lawn. Figure $2 \mathrm{~A}$ shows the substantial effect that these differing mean values of $t_{r}$ had on the rainfall-runoff relation. There is a trend of increasing soil moisture content from 11.5 to 43.5 percent as $t_{r}$ decreases from 0.72 to 0.2 hour 
Table 1. Soil characteristics and average Green-Ampt parameters for three locations on a single lawn

[\%, percent; $\mathrm{g} / \mathrm{cm}^{3}$, gram per cubic centimeter; $\mathrm{K}$, saturated hydraulic conductivity; $\mathrm{cm} / \mathrm{hr}$; centimeter per hour; $\mathrm{t}_{\mathrm{r}}$, time until runoff; hrs, hours; $\psi$, wetting front suction; $\mathrm{cm}$, centimeter; $\mathrm{R}^{2}$, correlation coefficient; --, not available]

\begin{tabular}{|c|c|c|c|c|c|c|c|c|}
\hline \multirow[b]{3}{*}{$\begin{array}{l}\text { Measure- } \\
\text { ment set }\end{array}$} & \multirow{2}{*}{\multicolumn{3}{|c|}{ Soil characteristics }} & \multicolumn{5}{|c|}{ Average Green-Ampt parameters } \\
\hline & & & & \multicolumn{4}{|c|}{ Model fit to measured data } & \multirow{2}{*}{$\begin{array}{c}\begin{array}{c}\text { Normalized } \\
\text { for equal soil } \\
\text { moisture }\end{array} \\
t_{r} \\
(h r s)\end{array}$} \\
\hline & $\begin{array}{c}\text { Soil } \\
\text { moisture } \\
\text { content } \\
(\%)\end{array}$ & $\begin{array}{c}\text { Bulk } \\
\text { density } \\
\left(\mathrm{g} / \mathrm{cm}^{3}\right)\end{array}$ & $\begin{array}{c}\text { Organic } \\
\text { matter } \\
\text { content } \\
(\%)\end{array}$ & $\begin{array}{c}\mathrm{K} \\
(\mathrm{cm} / \mathrm{hr})\end{array}$ & $\begin{array}{c}t_{r} \\
\text { (hrs) }\end{array}$ & $\begin{array}{c}\Psi \\
(\mathrm{cm})\end{array}$ & $\mathbf{R}^{2}$ & \\
\hline Location 1 & 11.5 & 1.1 & 9.0 & 0.52 & 0.72 & 58 & 0.95 & 0.51 \\
\hline Location 2 & 30.0 & 1.3 & 7.0 & .59 & .59 & 53 & .96 & .73 \\
\hline Location 3 & 43.5 & 1.2 & 6.7 & .77 & .20 & 4.3 & .99 & .32 \\
\hline p-values & - & -- & - & .53 & $6.6 \mathrm{E}-04$ & .12 & - & .08 \\
\hline
\end{tabular}

(table 1). It is believed that the difference between rainfall-runoff curves in figure $2 \mathrm{~A}$ was the result of the different antecedent soil moisture conditions. The literature supports the importance of antecedent soil moisture to the infiltration process (Tisdall, 1951; Istok and Boersma, 1986; Watschke and others, 1989). After normalizing the measurement sets for an equal antecedent soil moisture value, the mean values of the time of ponding, $t_{r}$ are no longer significantly different. In spite of the statistics, the rainfall-runoff relations for parameters normalized to an equal soil moisture content are quite different as seen in figure $2 \mathrm{~B}$. Although not statistically different, the difference in the rainfallrunoff relation as drawn would cause large discrepancies in the prediction of runoff.

Examination of the wetting front suction, $\psi$, helps explain the difference in the rainfall-runoff relations for locations within the same lawn. Normalization for equal soil moisture does not equalize the rainfall-runoff relations as expected because of the difference in the $\psi$ values between sites. Although $\psi$ functions well as a curve fitting parameter to calibrate the Green-Ampt model, it has no physical basis. It is possible that the $\psi$ parameter is compensating for an inability of the Green-Ampt model to consider preferential flow paths in the soil matrix (flow through macropores). In turfed areas this flow is considered an important factor in the infiltration process. The GreenAmpt model is based on flow through a homogenous soil matrix and does not consider macropores. By using an empirical value for $\psi$ in the model the effects of preferential flow in the field data are compensated for.
It is then difficult to use the model to predict runoff based on conditions other than those for which $\psi$ was derived. For this reason, the ability to predict the rainfall-runoff relation for equal initial soil moisture is limited.

To summarize, the runoff data collected within a single lawn shows that the hydraulic conductivities do not vary significantly. However, the entire rainfall-runoff relation as drawn in figure 2 does change substantially, possibly because of differences in the initial soil moisture that could not adequately be compensated for. Therefore, the hypothesis that there are no substantial differences in the rainfall-runoff relation within a single lawn is rejected.

The second hypothesis is confirmed. There are substantial differences in the rainfall-runoff relations for different lawns. For this part of the study, runoff measurements were made on three different lawns with four replications per lawn. Table 2 lists the soil characteristics, Green-Ampt parameters, and p-values for the three different treatment means. $\mathrm{R}^{2}$ correlation coefficients indicate an excellent model fit. The hydraulic conductivities, $K$, for the three different lawns are significantly different which suggests that the soil properties vary between lawns. The $t_{r}$ and $\psi$ values were not significantly different before or after normalization for an equal antecedent soil moisture content. Figure 3A shows the effect of the different hydraulic conductivities on the rainfall-runoff relation between lawns. Normalizing for soil moisture amplified this effect (fig. 3B). Whether the effects of different antecedent soil moisture are adequately compensated for or not in fig- 

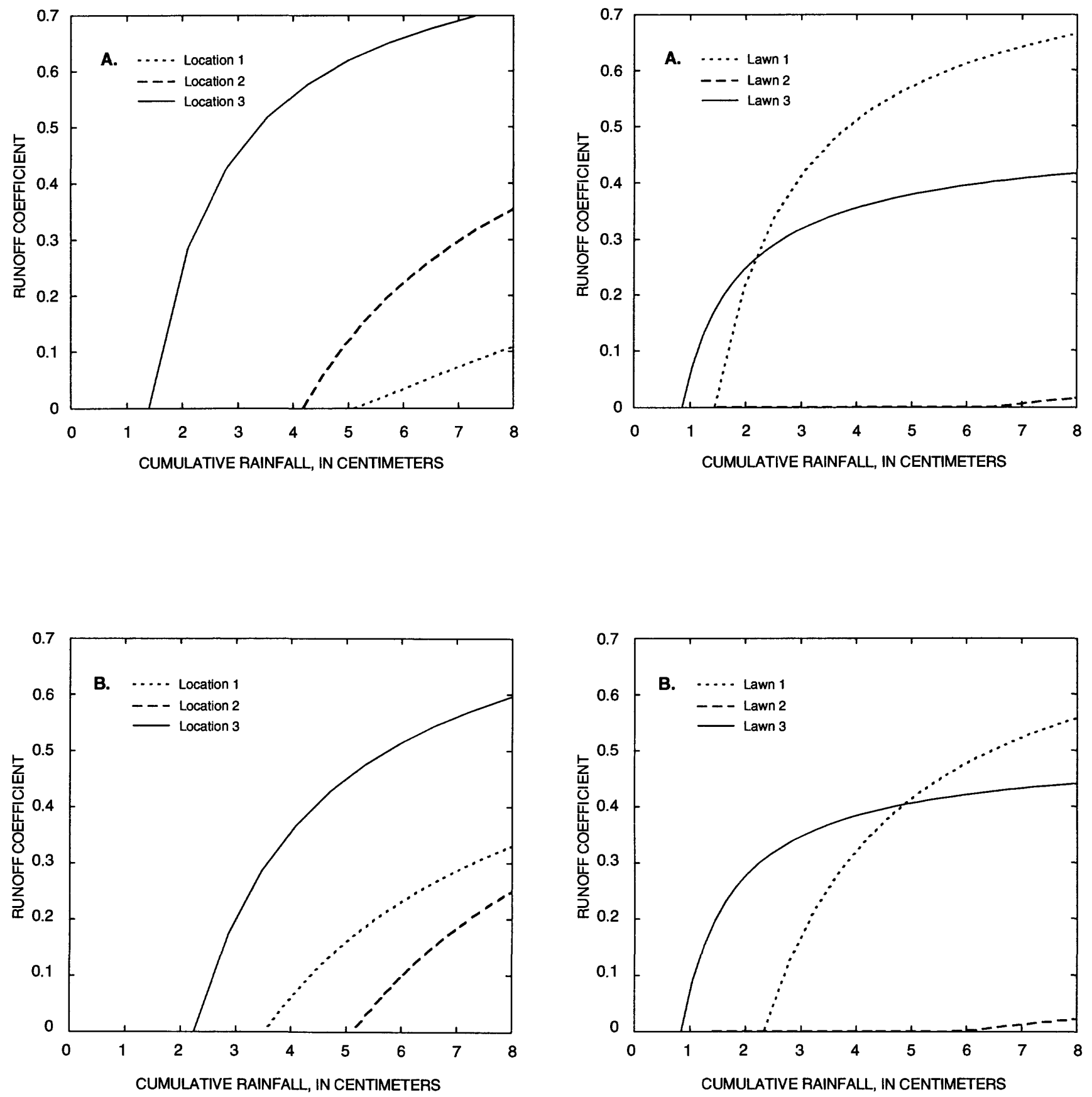

Figure 2. Cumulative rainfall versus runoff coefficients for three locations on the same residential lawn before and after normalization for equal antecedent soil moisture.

Figure 3. Cumulative rainfall versus runoff coefficients for three different lawns $(A)$ before and $(B)$ after normalization for equal antecedent soil moisture. 
Table 2. Soil characteristics and average Green-Ampt parameters for three different lawns [\%, percent; $\mathrm{g} / \mathrm{cm}^{3}$, gram per cubic centimeter; $\mathrm{K}$, saturated hydraulic conductivity; $\mathrm{cm} / \mathrm{hr}$; centimeter per hour; $\mathrm{t}_{\mathrm{p}}$ time until runoff; hrs, hours; $\psi$, wetting front suction; $\mathrm{cm}$, centimeter; $\mathrm{R}^{2}$, correlation coefficient; --, not available]

\begin{tabular}{|c|c|c|c|c|c|c|c|c|}
\hline \multirow[b]{3}{*}{$\begin{array}{l}\text { Measure- } \\
\text { ment set }\end{array}$} & \multirow{2}{*}{\multicolumn{3}{|c|}{ Soil characteristics }} & \multicolumn{5}{|c|}{ Average Green-Ampt parameters } \\
\hline & & & & \multicolumn{4}{|c|}{ Model fit to measured data } & \multirow{2}{*}{$\begin{array}{c}\begin{array}{c}\text { Normalized } \\
\text { for equal soil } \\
\text { moisture }\end{array} \\
t_{\mathbf{r}} \\
(h r s)\end{array}$} \\
\hline & $\begin{array}{c}\text { Soil } \\
\text { moisture } \\
\text { content } \\
(\%)\end{array}$ & $\begin{array}{c}\text { Bulk } \\
\text { density } \\
\left(\mathrm{g} / \mathrm{cm}^{3}\right)\end{array}$ & $\begin{array}{c}\text { Organic } \\
\text { matter } \\
\text { content } \\
(\%)\end{array}$ & $\begin{array}{c}\mathrm{K} \\
(\mathrm{cm} / \mathrm{hr})\end{array}$ & $\begin{array}{c}t_{r} \\
\text { (hrs) }\end{array}$ & $\begin{array}{c}\Psi \\
(\mathrm{cm})\end{array}$ & $\mathbf{R}^{2}$ & \\
\hline Lawn 1 & 34.9 & 1.4 & 3.5 & 0.84 & 0.20 & 9.2 & 1.0 & 0.32 \\
\hline Lawn 2 & 27.3 & 1.4 & 6.1 & 5.9 & .20 & 2.0 & 1.0 & .19 \\
\hline Lawn 3 & 13.7 & 1.3 & 6.9 & 3.5 & .12 & .23 & .99 & .12 \\
\hline p-values & -- & -- & -- & 2.7E-05 & .18 & .39 & -- & .08 \\
\hline
\end{tabular}

Table 3. Soil characteristics and average Green-Ampt parameters for five different age groups

$\left[\%\right.$, percent; $\mathrm{g} / \mathrm{cm}^{3}$, gram per cubic centimeter; $\mathrm{K}$, saturated hydraulic conductivity; $\mathrm{cm} / \mathrm{hr}$; centimeter per hour; $\mathrm{t}_{\mathrm{r}}$ time until runoff; hrs, hours; $\Psi$, wetting front suction; $\mathrm{cm}$, centimeter; $\mathrm{R}^{2}$, correlation coefficient; --, not available]

\begin{tabular}{|c|c|c|c|c|c|c|c|c|}
\hline \multirow[b]{3}{*}{ Years } & & & & \multicolumn{5}{|c|}{ Average Green-Ampt parameters } \\
\hline & \multicolumn{3}{|c|}{ Soil characteristics } & \multicolumn{4}{|c|}{ Model fit to measured data } & \multirow{2}{*}{$\begin{array}{c}\begin{array}{c}\text { Normalized } \\
\text { for equal soil } \\
\text { moisture }\end{array} \\
t_{\mathbf{r}_{\mathrm{r}}} \\
\text { (hrs) }\end{array}$} \\
\hline & $\begin{array}{c}\text { Soil } \\
\text { moisture } \\
\text { content } \\
(\%)\end{array}$ & $\begin{array}{c}\text { Bulk } \\
\text { density } \\
\left(\mathrm{g} / \mathrm{cm}^{3}\right)\end{array}$ & $\begin{array}{c}\text { Organic } \\
\text { matter } \\
\text { content } \\
(\%)\end{array}$ & $\begin{array}{c}K \\
(\mathbf{c m} / \mathbf{h r})\end{array}$ & $\begin{array}{c}t_{r} \\
\text { (hrs) }\end{array}$ & $\begin{array}{c}\psi \\
(\mathrm{cm})\end{array}$ & $\mathbf{R}^{2}$ & \\
\hline $1-3$ & 24.5 & 1.6 & 4.8 & 1.1 & 0.18 & 3.2 & 1.0 & 0.21 \\
\hline $7-9$ & 26.7 & 1.4 & 7.3 & 4.3 & .25 & 11 & .99 & .36 \\
\hline $13-18$ & 21.0 & 1.3 & 6.5 & 4.7 & .41 & 7.1 & 1.0 & .41 \\
\hline $41-46$ & 14.9 & 1.4 & 5.5 & 4.3 & .13 & .67 & 1.0 & .13 \\
\hline $65-70$ & 37.5 & 1.2 & 7.0 & 5.4 & .12 & .15 & 1.0 & .14 \\
\hline p-values & -- & -- & -- & .01 & .11 & .23 & -- & .11 \\
\hline
\end{tabular}

ure 3, the shape of the curve is very different. This supports the results of the statistical analysis that suggest a difference in soil properties between different lawns.

Confirmation of the second hypothesis established a significant difference between soil properties that control rainfall-runoff relations for different lawns. Expanding on this, the third hypothesis states that there is a relation between the age of a lawn and the volume of runoff from the lawn. This third part of the study consisted of the collection of data from lawns in five different age groups with four different lawns as replication, for a total of 20 lawns. Table 3 lists the soil characteristics, Green-Ampt parameters, and p-values for the five different age groups. The model fit was excel- lent with 4 of the 5 age groups having an $R^{2}$ value of 1.0. The hydraulic conductivities for individual age groups were compared using Tukey's method for multiple comparison. The results of this test showed significant differences among lawns in the age group 1-3 years and lawns in the age groups 13-18 years and 6570 years. The differences among age group 1-3 years and groups 7-9 years and 41-46 years were close to having statistical significance with p-values of 0.066 and 0.064, respectively. Age groups over 1-3 years had no statistical difference when individually compared to one another. It was confirmed that the hydraulic conductivity of new lawns, ages 1-3 years, are significantly lower than those for older lawns. Differences 

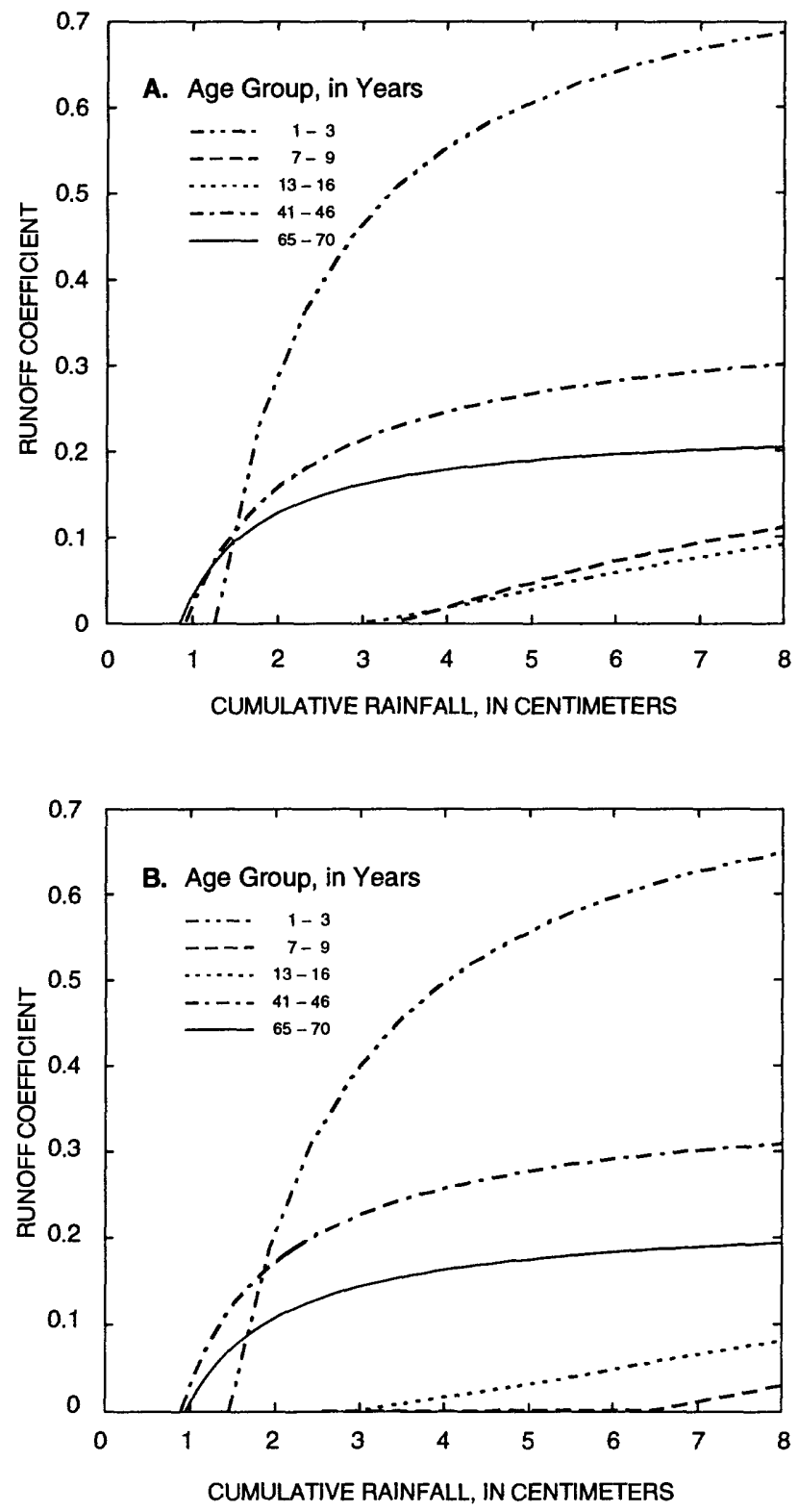

Figure 4. Cumulative rainfall versus runoff coefficients for five different lawn age groups $(A)$ before and $(B)$ after normalization for equal antecedent soil moisture.

among the lawns older than the 1-3 year age group could not be distinguished. The different hydraulic conductivities had a substantial effect on rainfall-runoff relations as shown in figure $4 \mathrm{~A}$, which displays the highest runoff coefficients with youngest age group.

Normalizing for soil moisture had little effect on the rainfall-runoff relations (fig. 4B). As discussed previously, the normalization procedure is limited by the empirical nature of $\psi$. The soil moisture for age-group treatment $65-70$ is 37.5 percent. The effect of normalizing to an average soil moisture of 21 percent may in fact be much greater if the $\psi$ values did not vary considerably.

The significantly lower hydraulic conductivity and high runoff coefficients for lawns in the 1-3 year age group are recognized in the bulk density and organic matter content data collected from the soil surface. The bulk density for the 1-3 year age group is higher than that of any other age group, and the organic matter content for the 1-3 year age group is less (table 3). Bulk density is a measure of porosity and soil structure. Organic matter content is an indication of the amount of biological activity, including grass-root growth in the top layer of the soil. The trends in bulk density and organic matter data from the 1-3 year age group to older lawns represent an increase in infiltration. It is generally accepted that development of soil structure and macropores increases infiltration. The significant decrease in runoff from age group 1-3 years to older lawns appears consistent with the findings of others. Beven and Germann (1986) and Hino and Shutto (1987) both reported the development of preferential flow within 2 years.

To begin to understand the effect of rainfall intensity on the runoff from residential lawns, a single lawn was tested at varying intensities. The rainfall simulator was run at $3.8,7.1$, and $14.0 \mathrm{~cm} / \mathrm{hr}$ with the same antecedent soil moisture conditions. The relation of rainfall to runoff at the three different intensities are shown in figure 5 . Contrary to what might be expected, the relations for different intensities are similar. This may be a result of a change in the available pore space, $n$. As intensity of rainfall increases surface water ponding on the measurement site is likely to increase. The increased pressure head due to ponding may contribute to a larger volume of rainfall infiltrating. Data sufficient to quantify this effect were not collected.

Data also were collected from residential lawns with sandy soil texture. Preliminary results of these tests compare well with hydraulic conductivities collected for silt loam soils. Rainfall simulator measurements on lawns with loamy sand soil for 5-, 15-, and $70+-$ year-old lawns had hydraulic conductivities of $2.6,3.4$, and $5.7 \mathrm{~cm} / \mathrm{hr}$, respectively. Similarly, the hydraulic conductivities for the silt loam soil increased from $1.1 \mathrm{~cm} / \mathrm{hr}$ for age group $1-3$ years to $5.4 \mathrm{~cm} / \mathrm{hr}$ for age group 65-70 years. These preliminary data show that changes in soil texture may not be an important 


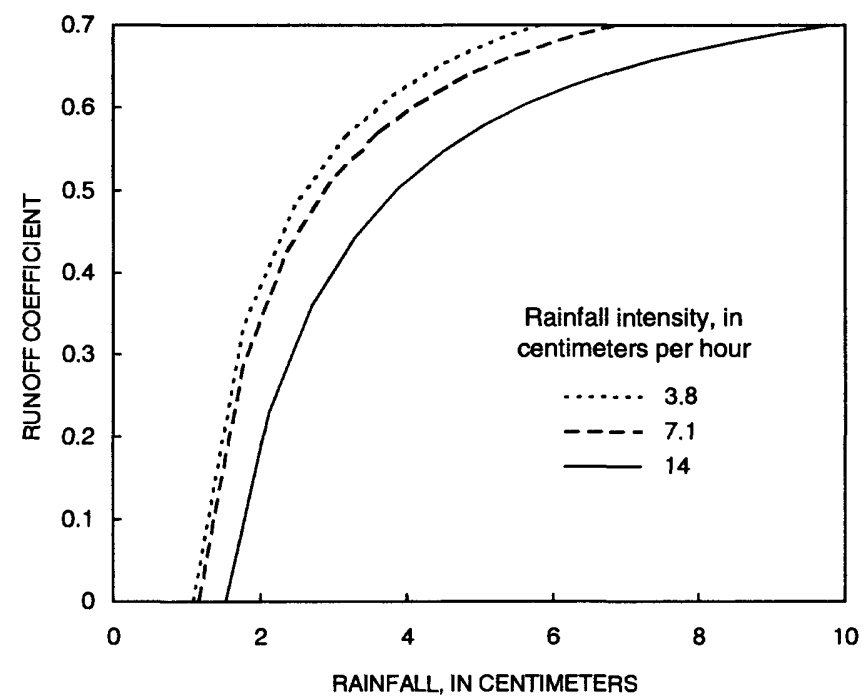

Figure 5. Runoff coefficients for a single lawn for three different rainfall intensities.

factor contributing to the variation in runoff volumes from lawns.

\section{SUMMARY AND CONCLUSIONS}

Determining the factors that most affect runoff volumes from residential lawns would improve the estimation of pollutant loads from urban watersheds. Fundamental to determining which factors contribute to runoff is quantifying the variation in the rainfall-runoff relation on residential lawns.

In this study, it was determined that the hydraulic conductivities do not vary significantly for a single residential lawn. The entire rainfall-runoff relation does change substantially, possibly because of differences in the initial soil moisture. From one lawn to another lawn there is substantial variation in the relation of rainfall to runoff. The difference between the hydraulic conductivity of newly established lawns and that of lawns 1-3 years old and older is statistically significant. Also, runoff coefficients for the young lawns are substantially greater than those for older lawns. The variability in the rainfall-runoff relation for lawns other than those newly developed cannot be explained by the age of a lawn. It is concluded that the age of a lawn would only be a useful parameter in determining runoff volume and pollutant loads from newly established residential lawns, those three years old or younger.

The effect of antecedent soil moisture on the results of this study is questioned. Because of the inability of the Green-Ampt model to account for flow through macropores, applicability of the soil moisture normalization procedure used in this study may be limited. For this reason definitive conclusions are not drawn regarding the variation of the runoff process on a single lawn. Also for this reason, a trend in decreasing runoff for older lawns could not be obviously distinguished.

Preliminary data show variation in rainfall intensity and variation in the soil texture had little effect on the runoff volumes. Data collected on residential lawns with sandy soil texture demonstrate similar hydraulic conductivities as those from silt loam soils. Future studies would need to include a variety of soil textures and rainfall intensities to substantiate these results.

This study explores the variation in the relation of rainfall to runoff from residential lawns. It is concluded that the rainfall-runoff relation varies substantially among different lawns. The age of a lawn, or the years since development and turf establishment, is used as a surrogate of several lawn and soil characteristics to describe this variation. Lawns established within three years produce higher runoff volumes than older lawns. This is an important consideration when modeling runoff for new developments. For older lawns, the date since lawn establishment does not explain the variation in the rainfall-runoff relation. In order for simple landuse based computer models to adequately account for the volume of runoff from pervious landscapes, field data from individual lawns would be necessary. A more realistic, alternative method may be to consider a basin-scale analysis of runoff from pervious landscapes.

\section{REFERENCES CITED}

Bannerman, R.T., Legg, A.D., and Greb, S.R., 1996, Quality of Wisconsin stormwater, 1989-94: U.S. Geological Survey Open-File Report 96-458, 26 p.

Beven, Keith, and Germann, Peter, 1982, Macropores and water flow in soils: Water Resources Research, v. 18, no. 5 , p. 1311-1325.

Devaurs, Micheline and Gifford, G.F., 1986, Applicability of the Green and Ampt infiltration equation to rangelands: Water Resources Bulletin, v. 22, no. 1, p. 19-26.

Gardner, W.H., 1986, Water content, in Methods of soil analysis, part 1: Physical and mineralogical methods: Madison, Wis., American Society of Agronomy, p. 493507. 
Glocker, C.L., and Patzer, R.A., 1978, Dane County soil survey: Madison, Wisconsin, Soil Conservation Service, p. $150-151$.

Gross, C.M., Angle, J. S., Hill, R.L., and Welterlen, M.S., 1991, Runoff and sediment losses from tall fescue under simulated rainfall: Journal of Environmental Quality, v. 20, p. 604-607.

Hamilton, G.W., Jr., 1990, Infiltration rates on experimental and residential lawns: University Park, Penn State University, Master's thesis.

Helsel, D.R., and Hirsch, R.M., 1995, Statistical methods in water resources: Amsterdam, Elsevier Science Publishers, p. 158-166 and p. 196-198.

Hino, Mikio, and Shutto, Hideharu, 1987, A laboratory experiment on the role of grass for infiltration and runoff processes: Journal of Hydrology, v. 90, p. 303-325.

Huff, F.A., and Angel, J.R., 1992, Rainfall frequency atlas of the Midwest: Champaign, Illinois State Water Survey, Bulletin 71, $141 \mathrm{p}$.

Ishtok, J.D., and Boersma, L., 1986, Effect of antecedent rainfall on runoff during low-intensity rainfall: Journal of Hydrology, v. 88, p. 329-342.

Kelling, K.A., and Peterson, A.E., 1975, Urban lawn infiltration rates and fertilizer runoff losses under simulated rainfall: Soil Science Society of America Proceedings, v. 39 , no. 2, p. 348-352.

Kussow, W.R., 1994, Soil disturbance effects on nutrient losses from turf: Wisconsin Turf Research Report 12, p. $95-100$.

Mein, R. G., and Larson, C. L., 1973, Modeling infiltration during a steady rain: Water Resources Research, v. 9, no. 2 , p. 384-394.
Partsch, C.M., Jarrett, A.R., and Watschke, T.L., 1993, Infiltration characteristics of residential lawns: American Society of Agricultural Engineers, v. 36, no. 6, p. 16951701.

Peterson, A.E., and Bubenzer, G.D., 1986, Intake ratesprinkler infiltrometer, in Methods of soil analysis, part 1: Physical and mineralogical methods: Madison, Wis., American Society of Agronomy, p. 845-867.

Pitt, Robert, 1986, Runoff controls in Wisconsin's priority watersheds, in Urbonas, B., and Roesner, L.A., eds., Urban runoff quality-Impact and quality enhancement Technology: Proceedings of an Engineering Foundation Conference, Henniker, N.H., p. 290-313.

Rawls, W.J., and Brakensiek, D.L., 1989, Estimation of soil water retention and hydraulic properties, in Unsaturated Flow in Hydrologic Modeling Theory and Practice, Kluwer Academic Publishers, p. 275-300.

Rawls, W.J., Brakensiek, D.L., and Saxton, K.E., 1982, Estimation of soil water properties: Transactions of the American Society of Agricultural Engineers, p. 13161320.

Tisdall, A.L. 1951, Antecedent soil moisture and its relation to infiltration: Australian Journal of Agricultural Research, v. 2, p. 342-348.

Watschke, T.L., Mumma, R.O., Harrison, S.A., and Hamilton, G.W., Jr., 1989, The effect of nutrients and pesticides applied to turf on the quality of runoff and percolating water: University Park, Penn., Environmental Resources Research Institute, ER 8904, 1 p. 